\title{
Professional Development of Mathematics Teachers in Najran: Opportunities and Challenges
}

\author{
Mohammed Mofreh Yahya Aseeri* \\ Department of Curriculum and Instruction, Najran University, KSA \\ *Corresponding author: aseerimoh@hotmail.com
}

Received October 24, 2019; Revised November 26, 2019; Accepted December 05, 2019

\begin{abstract}
The present study aimed to identify the main opportunities with which professional development programs provide mathematics teachers at the Education Directorate at Najran. It also aimed to determine the most important challenges these teachers usually face at schools. Therefore, a four- aspect questionnaire to investigate the teachers' viewpoint about classroom teaching practices, resources of professional development, obstacles of professional development, in addition to opportunities and challenges of professional development programs was developed. Then it was delivered to (115) participants among which were (42) males and (73) females. They were all teaching mathematics at the three education stages at public schools at Najran in the academic year 2018/ 2019. The descriptive analytical approach was used to interpret collected data. Results indicated that professional development programs were very effective in improving mathematics teacher' classroom teaching practices, making them more aware of their professional development resources and more capable in distinguishing the main obstacles that hinder their profession. Findings also showed that there were significant differences between participants' responses due to gender in favor of females. Moreover, there were significant differences due to the educational stage in favor of the intermediate and secondary stages. There were also significant differences due to the number of programs teachers received in favor of more than five development programs. Nevertheless, there were no differences due to the teaching experience. Results also showed that the big increase in student's numbers inside classrooms, the length of the teaching material, the frequent absence of students, and the difficulty to follow up the latest in his area of specialty were the most important challenges facing mathematics teachers. Opportunities provided by professional development programs were not highly available because most of the required services mainly health ones did not exist.
\end{abstract}

Keywords: professional development, mathematics teachers, obstacles of professional development, opportunities of professional development, challenges of professional development, and teaching practices

Cite This Article: Mohammed Mofreh Yahya Aseeri, "Professional Development of Mathematics Teachers in Najran: Opportunities and Challenges.” American Journal of Educational Research, vol. 7, no. 12 (2019): 907-918. doi: 10.12691/education-7-12-3.

\section{Introduction}

The need for professional development always exists because it is impossible for the teacher to keep living with a limited set of knowledge and skills acquired at preparation institutions, which, in turn do not empower him to perform his new roles and responsibilities because of scientific and information progress in the present era. Therefore, he has to keep looking for a renewed level of information, skills and modern trends in teaching methodology. Teaching for him should be a continuous process because a good and creative teacher is someone who seeks knowledge in an ever changing and developing society. Thus, it is urgent to provide the teacher with the latest in all scientific and educational fields like educational methods and techniques because of the difficulties facing his preparation to be fit for any time and place in light of ICT revolution. This, in turn, needs preparing programs for teacher's professional development under the supervision of a group of capable and specialized educators to keep professionally developing this teacher in accordance to modern trends and technologies in teaching [1]. Today's teacher should keep pace with successive changes and developments and comprehend the multiplicity in his roles and responsibilities. He, after being the main source of and a lecturer for information, has to direct his students and motivate them to discover not recite such information. He also has to promote the attitudes and skills students need to face future challenges [2]. Attention to enhancing the teacher's level and developing him professionally positively and directly affects students' achievement level in addition to the positive impact on school curriculum, methodology, fostering teacher's sense of commitment to develop his professional experience that will allow more and more opportunities for students' learning [3].

Teachers of mathematics, as an important element in the educational process, highly need professional 
development because of the great importance this subject has and the big difference that distinguishes it from other subjects. Mathematics as a teaching subject represents a harmonized and balanced mixture of content and modern teaching methodology [4]. Mathematics, in addition to the fact that it is one of the main components of all natural sciences and an important tool to solve current live problems, it is an effective element in scientific development and an important indicator on the availability of technological progress rectifiers [5]. Moreover, effective teaching of mathematics requires a teacher who has the mathematical knowledge; experience regarding the curriculum aims, classroom environment, and students' needs; owns planning skills and implantation via providing students with suitable opportunities to achieve effective learning besides the assessment skills to assess what students learn successfully [6]. Therefore, developed countries seriously seek to improve their students' achievement level in most teaching materials to succeed in international exams like for instance, Trends of the International Mathematics and Science studies (TIMSS) and Program for International Student Assessment (PISA). Henceforth, developed countries started orienting their attention towards the teacher and developing his knowledge and skills because they believe that there is a strong relation between teacher's empowerment, the quality of teaching, and the achievement level of pupils [7].

Most countries, among which is Saudi Arabia, have started paying attention to carry out professional development programs for mathematics teachers to help them develop their teaching capabilities in line with current directions of specialized international organization in teacher preparation and training like for example, Interstate New Teacher Assessment and Support Consortium (INTASC), National Board for Professional Teaching Standards (NBPTS) and National Council For Teacher of Mathematics (NCTM) [2]. All these organizations are keen to prepare plans and set standards for mathematics' teachers training through programs of professional development that include specialized, cognitive, cultural and social aspects because previous training programs worked on teachers' rehabilitation to teach old curricula. Furthermore, current curricula have been developed while teachers have not been professionally developed and trained to implement these modern curricula [7]. In brief, developed curricula need the promotion of teacher's communication, mathematical interdependence and higher order thinking skills; ICT activation in teaching; the ability to use dialogue in classroom environment and other skills that cannot be promoted in short training courses which poses a new challenge on mathematics teachers to be enrolled in professional development programs to go along with the comprehensive development in these curricula and to achieve the aims of teaching them [5].

\subsection{Statement of the Problem}

Teacher preparation and professional development has become one of the most fateful issues imposed by life developments and the era of rapid challenges and changes that have driven countries all over the world to reconsider their educational systems, in general and teacher preparation and development, in particular. They have introduced programs that aim to provide teachers with needed educational experience and help them acquire essential professional skills, in order to go along with the latest in the field of technological knowledge and information; interact, produce and contribute to pushing the wheel of progress and prosperity.

In Saudi Arabia, as well as other countries, Ministry of Education has started a great project for the development of mathematics curricula through the adoption of teaching McGraw-Hill, which is one of the American teaching series, in all public education stages. This project mainly focuses on developing or re-organizing mathematics curricula in harmony with international standards and stresses the importance of using varied teaching strategies to deliver the teaching content [11] and [8]. Therefore, the main objective of the present study is to identify the reality of mathematics teachers' professional development in light of this great project, i.e. the adoption of McGraw Hill series, in Saudi Arabia in general and more specifically in Najran region. It in particular seeks to identify the opportunities such program provides teachers with and the obstacles it faces in reality by answering these questions:

1) How effective are the professional development programs in improving classroom teaching practices of mathematics teachers at Najran?

2) Are there any significant differences between participants' responses to the effectiveness of the professional development programs of mathematics teachers due to gender?

3) Are there any significant differences between participants' responses to the effectiveness of the professional development programs of mathematics teachers due to the teaching stage?

4) Are there any significant differences between participants' responses to the effectiveness of the professional development programs of mathematics teachers due to the teaching experience?

5) Are there any significant differences between participants' responses to the effectiveness of the professional development programs of mathematics teachers due to the number of provided professional development programs?

6) What are the main opportunities and challenges of the professional development programs of mathematics teachers in Najran?

\section{Theoretical Framework and Related Literature}

\subsection{Professional Development}

The present era requires the presence of a teacher who effectively takes part in developing the educational process by his constructive suggestions and remarks. Efficacy of developed curricula, aids teaching tools will not be achieved unless there is a competent teacher who can by using his knowledge and skills, benefit from these tools to promote the educational process. In current literature, the topic of professional development has a vast space because of its core importance in education and 
effective role in promoting the teacher's cognition and skills. Professional development has been referred to, in some studies, as in-service training, professional growth and later on, as continuous professional development and teacher training. All these concepts nearly indicate the concept of professional development with some philosophical and professional variation [9]. The main cause of this shift in terminology use might be due to the teacher's role and the change in professional development aims. In the $1970_{\mathrm{s}}$ and $1980_{\mathrm{s}}$, professional development programs aimed to increase teachers' knowledge through specialists and experts from outside school. In the nineties of the same century, it was expanded to engage the organizations to which they belong. In the new millennium, the trend has been to design programs to help teachers deeply comprehend the processes of teaching and learning via the direct experience that help students to learn using effective methods [10].

Professional development is every new thing the teacher acquires whether academically, culturally, or professionally and contributes to the improvement of his performance and control over his problems related to teaching methods, motivating students or the nature of the teaching material. Therefore, a teacher can professionally grow as soon as he overcomes a problem [11]. It is every activity the person performs, receives, or participates in resulting in acquiring new experience, modifying conduct besides developing and updating his previous experience involving skills and capabilities. Moreover, a process aims to add knowledge and develop both skills and professional values within the teacher to achieve effective education for students and positive learning outcomes [16] and [12]. On the other hand, it as a continuous developmental process of multi dimensions related to teaching inside and outside school based methodological plans and implementation of enrichment programs and projects to help developing the teacher's performance in all aspects [13]. In addition, professional development is a continuous process through which change in teacher's concepts and practices regarding the teaching methods and curricula to find new ways that fulfills the teaching needs [14,15,16,21].

In brief, professional development aims to promote the teacher's professional level through providing a set of continuous and in advance planned programs and activities by specialized institutions. The teacher should be able to deal with varied forms of new technology. He should be able to go along with successive changes so that he can contribute to solving community problems in general and the educational institution, particularly. That is, professional development aims to enhance the teacher's performance in light of changes and requirements in this era by providing him with competences and skills that help him better performs his duties.

\subsection{Aims of Professional Development}

Apart from the fact that most, if not all, professional development programs aim to promote the teacher's personality scientifically, academically and behaviorally to best do his jobs, they try to implant the sense of desire to improve his capabilities and skills along with current changes. They for instance, aim to achieve quality in education and form positive attitudes towards this profession. Besides, they aim to enable teachers to face and adapt to educational changes and reforms through making clear educational system problems and make a joint between theoretical and practical skills [14]. Professional development programs also aim to increase teacher's specialized understanding and his knowledge of assessment applications and alternatives; skills of questioning, writing, discussion and dialogue; and apply teaching models and strategies that activate his role [10]. One more aim of these programs is to enable the teacher to keep along with the latest in the field of the educational theories and the content of the curricula to achieve self-confidence, better students' achievement and effectiveness in teaching [2]. Programs of professional development make a connection between theory and practice in teaching. They enhance the creative aspects within teachers and cooperation with colleagues to solve problems they face. In addition, they enable teachers to use information resources, search for the newest in teaching methodology, encourage them to be lifelong learners and apply educational theories inside and outside classrooms [17].

\section{Methodology}

\subsection{Study Approach}

The present study adopted the descriptive approach, which is believed to be the most appropriate to answer the questions about the reality of mathematics teachers professional development programs in accordance with the opportunities they provide and the challenges they meet.

\subsection{Population}

Population of the present study involved all mathematics teachers in in the three educational stages, elementary, intermediate, and secondary, in Najran region in the academic year 2018/2019.

\subsection{Sample}

The sample consisted of (115) teachers who were all teaching mathematics in the elementary, intermediate and secondary stages in the public schools in the Directorate of Education in Najran. Table 1 shows the distribution of study sample.

\subsection{Instrument}

The study instrument consisted of a four-dimension questionnaire mainly, classroom practices, sources of professional development, obstacles of professional development, opportunities and challenges facing mathematics teachers. Independent variables like gender, educational stage, years of experience and number of professional development programs were accounted for. For the sake of making data analysis easier, a weight was assigned for each response to every question in the questionnaire starting from "5" points for "strongly agree" 
"4" points for "agree", "3" points for "neutral", "2" points for "disagree" and "1" point for "strongly agree". Table 2 presents the criterion for eliciting data and explaining mean scores.

\subsection{Validity of the Questionnaire}

Validity coefficient was calculated in two ways.
1. Face validity or what is known as arbitrators' validity where the questionnaire was presented to a set of arbitrators to judge whether the included items can really test what they were developed to.

2. Construct validity or what is known as internal consistency.

Correlation coefficients of items in each dimension in the questionnaire are presented in Table 3.

Table 1. Distribution of sample

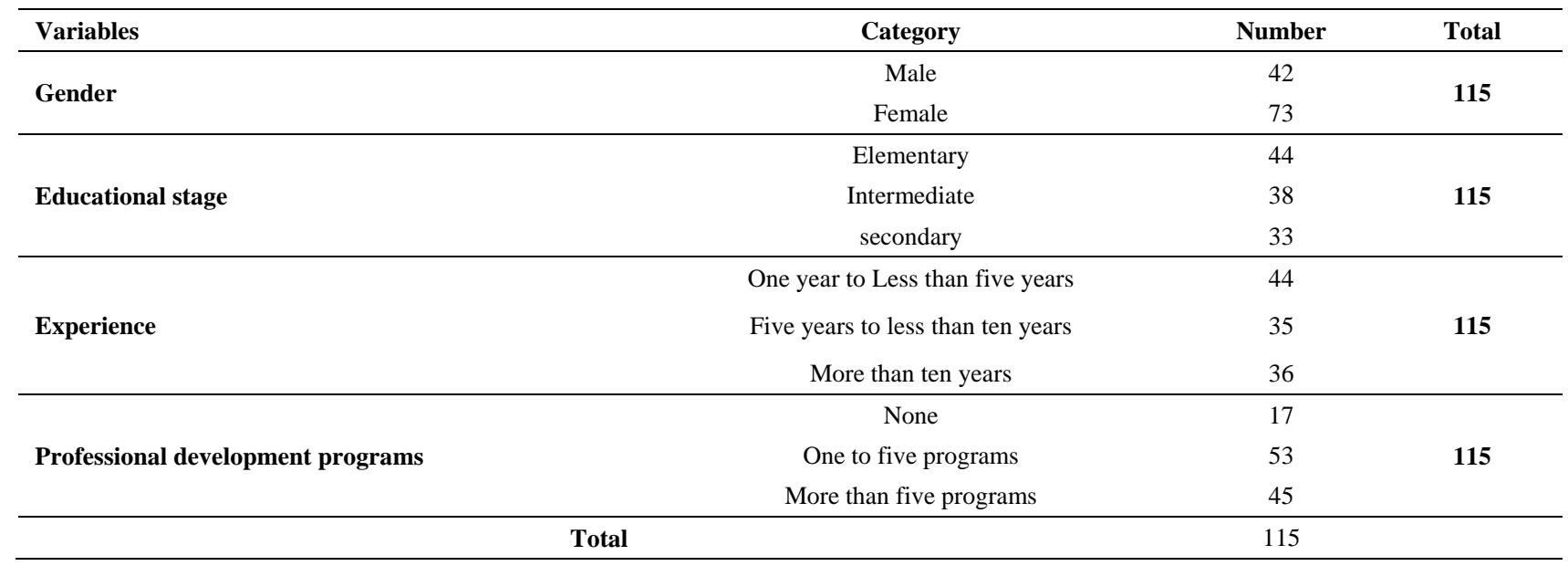

Table 2. Data eliciting criterion and mean scores explanation

\begin{tabular}{|c|c|c|c|}
\hline Response Number & Mean score extent & Agreement degree & Availability degree \\
\hline 1 & $1.00-1.80$ & Strongly disagree & Too low \\
\hline 2 & $1.81-2.60$ & Disagree & Low \\
\hline 3 & $2.61-3.40$ & Neutral & Moderate \\
\hline 4 & $3.41-4.20$ & Agree & High \\
\hline 5 & $4.20-5.00$ & Strongly agree & Very high \\
\hline
\end{tabular}

Table 3. Correlation coefficients of items in the questionnaire four dimensions

\begin{tabular}{|c|c|c|c|c|c|c|c|}
\hline Ques. & Correlation Coefficient & Question & Correlation Coefficient & Question. & Correlation Coefficient & Question & Correlation Coefficient \\
\hline \multicolumn{8}{|c|}{ The first dimension: Classroom teaching practices of mathematics teachers } \\
\hline 1 & $0.688 * *$ & 2 & $0.624^{* *}$ & 3 & $0.667 * *$ & 4 & $0.673^{* *}$ \\
\hline 5 & $0.517 * *$ & 6 & $0.541^{* *}$ & 7 & $0.714^{* *}$ & 8 & $0.597 * *$ \\
\hline 9 & $0.457 * *$ & 10 & $0.632 * *$ & 11 & $0.717 * *$ & 12 & $0.629 * *$ \\
\hline 13 & $0.474 * *$ & 14 & $0.607 * *$ & 15 & $0.587 * *$ & & \\
\hline \multicolumn{8}{|c|}{ The second dimension: Resources of mathematics teachers' professional development } \\
\hline 16 & $0.665 * *$ & 17 & $0.747 * *$ & 18 & $0.767 * *$ & 19 & $0.754 * *$ \\
\hline 20 & $0.786^{* *}$ & 21 & $0.688 * *$ & 22 & $0.625^{* *}$ & 23 & $0.657 * *$ \\
\hline 24 & $0.641^{* *}$ & 25 & $0.461^{* *}$ & 26 & $0.698 * *$ & 27 & $0.659 * *$ \\
\hline 28 & $0.463^{* *}$ & 29 & $0.696 * *$ & 30 & $0.696^{* *}$ & & \\
\hline \multicolumn{8}{|c|}{ The third dimension: Obstacles of mathematics teachers' professional development } \\
\hline 31 & $0.576^{* *}$ & 32 & $0.786^{* *}$ & 33 & $0.453^{* *}$ & 34 & $0.480 * *$ \\
\hline 35 & $0.636^{* *}$ & 36 & $0.724^{* *}$ & 37 & $0.714^{* *}$ & 38 & $0.766^{* *}$ \\
\hline 39 & $0.609 * *$ & 40 & 0.687 & 41 & $0.503^{* *}$ & 42 & $0.580 * *$ \\
\hline 43 & $0.554^{* *}$ & 44 & $0.498 * *$ & 45 & $0.444^{* *}$ & & \\
\hline \multicolumn{8}{|c|}{ The fourth Dimension: Opportunities and challenges of professional development facing mathematics teachers } \\
\hline 46 & $0.341^{* *}$ & 47 & $0.678 * *$ & 48 & $0.402 * *$ & 49 & $0.517 * *$ \\
\hline 50 & $0.595^{* *}$ & 51 & $0.583^{* *}$ & 52 & $0.537 * *$ & 53 & $0.539 * *$ \\
\hline 54 & $0.523 * *$ & 55 & $0.567 * *$ & 56 & $0.666 * *$ & 57 & $0.530 * *$ \\
\hline 58 & $0.611^{* *}$ & 59 & $0.736^{* *}$ & 60 & $0.544^{* *}$ & 61 & $0.689 * *$ \\
\hline 62 & $0.730 * *$ & 63 & $0.718^{* *}$ & 64 & $0.713^{* *}$ & & \\
\hline
\end{tabular}

$* *$ : 0.01 significant when $\alpha=0.01$. 
Table 4. Correlation coefficient between the score of each dimension and the total questionnaire score

\begin{tabular}{ll}
\hline Dimensions of the questionnaire & Correlation Coefficients \\
\hline Dimension 1: Mathematics teachers' classroom teaching practices & $0.546^{* *}$ \\
Dimension 2: Mathematics teachers' professional development resources & $0.525^{* *}$ \\
Dimension 3: Mathematics teachers' professional development obstacles & $0.639^{* *}$ \\
Dimension 4: Opportunities and challenges of professional development & $0.757^{* *}$ \\
\hline
\end{tabular}

**: 0.01 significant when $\alpha=0.01$.

Correlation coefficient between the score of each dimension and the total questionnaire score are shown in Table 4.

Table 3 \& Table 4 reveal that the questionnaire is internally consistent whether at the level of items, dimension or the instrument as a whole. That is, results can be trusted as soon as the questionnaire applied to participants.

\subsection{Reliability of the Questionnaire}

Cronbach Alpha was utilized to check the questionnaire's reliability coefficients, results are presented in Table 5.

Table 5. Cronbach Alpha coefficients of questionnaire's reliability

\begin{tabular}{lcc}
\hline Dimension & $\begin{array}{c}\text { N. of } \\
\text { items }\end{array}$ & $\begin{array}{c}\text { Reliability } \\
\text { Coefficient }\end{array}$ \\
\hline $\begin{array}{l}\text { Dimension 1: Mathematics teachers' } \\
\text { classroom teaching practices }\end{array}$ & 15 & 0.864 \\
$\begin{array}{l}\text { Dimension 2: Mathematics teachers' } \\
\text { professional development resources } \\
\text { Dimension 3: Mathematics teachers' } \\
\text { professional development obstacles } \\
\begin{array}{l}\text { Dimension 4: Opportunities and challenges of } \\
\text { professional development facing mathematics } \\
\text { teachers }\end{array}\end{array}$ & 15 & 0.910 \\
\hline Total Number & 19 & 0.833 \\
\hline
\end{tabular}

Results in Table 5 indicate that Cronbach alpha reliability coefficients for each dimension and for the questionnaire as a whole were ranging between (0.833) and (0.910). Reliability coefficient for the questionnaire as a whole was (0.899). In other words application of the questionnaire can guarantee reliable results once distributed and responded to by study participants.

\subsection{Description of the Sample}

Table 6, Table 7, Table 8, and Table 9 show the distribution of the study sample

Table 6. Distribution of sample with regard to gender

\begin{tabular}{cccc}
\hline Number & Gender & Frequency & Proportion \\
\hline $\mathbf{1}$ & Male & 42 & $37 \%$ \\
$\mathbf{2}$ & Female & 73 & $63 \%$ \\
\hline Total & & $\mathbf{1 1 5}$ & $\mathbf{1 0 0 \%}$ \\
\hline
\end{tabular}

Table 7. Distribution of sample with regard to the teaching stage

\begin{tabular}{cccc}
\hline Number & Teaching stage & Frequency & Proportion \\
\hline $\mathbf{1}$ & Elementary & 44 & $38 \%$ \\
$\mathbf{2}$ & Intermediate & 38 & $33 \%$ \\
$\mathbf{3}$ & Secondary & 33 & $29 \%$ \\
\hline Total & & $\mathbf{1 1 5}$ & $\mathbf{1 0 0 \%}$ \\
\hline
\end{tabular}

Table 8. Distribution of sample with regard to years of teaching experience

\begin{tabular}{clcc}
\hline Number & $\begin{array}{l}\text { Years of teaching } \\
\text { experience }\end{array}$ & Frequency & Proportion \\
\hline $\mathbf{1}$ & $\begin{array}{l}\text { One year to Less } \\
\text { than five years }\end{array}$ & 44 & $38 \%$ \\
$\mathbf{2}$ & $\begin{array}{l}\text { Five years to less } \\
\text { than ten years }\end{array}$ & 35 & $31 \%$ \\
$\mathbf{3}$ & More than ten years & 36 & $31 \%$ \\
\hline Total & & $\mathbf{1 1 5}$ & $\mathbf{1 0 0 \%}$ \\
\hline
\end{tabular}

Table 9. Distribution of sample with regard to the number of attended professional development programs

\begin{tabular}{clcc}
\hline Number & \multicolumn{1}{c}{$\begin{array}{c}\text { Number of development } \\
\text { programs }\end{array}$} & Frequency & Proportion \\
\hline $\mathbf{1}$ & None & 17 & $15 \%$ \\
$\mathbf{2}$ & $\begin{array}{l}\text { One program to five } \\
\text { programs }\end{array}$ & 53 & $46 \%$ \\
$\mathbf{3}$ & More than five programs & 45 & $19 \%$ \\
\hline Total & & $\mathbf{1 1 5}$ & $\mathbf{1 0 0 \%}$ \\
\hline
\end{tabular}

\section{Results and Discussion}

\subsection{Results Related to the First Question}

To answer the first question "How effective are the professional development programs in improving your classroom teaching practices as a teacher of mathematics?" Mean scores and standard deviations for participants' responses were extracted as shown in Table 10, Table 11, and Table 12.

Findings in Table 10 indicate that the teaching practices were available to a very high degree $(M=4.29)$. Mean scores of participants' responses extended from high $(\mathrm{M}=3.87)$ and very high $(\mathrm{M}=4.74)$. One interesting explanation of this high mean score of this dimension may be because of the teachers' competency in preparing students; their focus, while teaching the scientific content, on issues related to students' life; and the use of varied teaching methods. Provision of opportunities by teachers to engage students in gathering, organizing and analyzing data; teachers' utilization of available tools to teach mathematics in addition to their employment of suggested plans and methods included in the teacher's guide to carry out the lesson were also of effective role in this high mean score. Other factors like, for example, encouraging students to think critically and creatively; utilizing active learning strategy, problem solving approach and cooperative learning; and helping students to implement projects and make leaflets were also of great assistance to raise participants' awareness of their teaching practices. 
Table 10. Mean scores and standard deviations of participants' responses to classroom teaching practices items

\begin{tabular}{|c|c|c|c|c|c|}
\hline N. & Teaching practices & M. & SD & Rank & Availability degree \\
\hline 1 & I prepare students at the beginning of the lesson. & 4.74 & 0.497 & 1 & Very high \\
\hline 2 & While teaching the scientific content, I focus on issues from students' life reality. & 4.24 & 0.844 & 10 & Very high \\
\hline 3 & I use varied methods to teach the scientific content. & 4.48 & 0.667 & 4 & Very high \\
\hline 4 & I engage students in data gathering, organizing and explaining. & 4.36 & 0.691 & 8 & Very high \\
\hline 5 & I use the available tools to teach mathematics. & 4.41 & 0.700 & 6 & Very high \\
\hline 6 & I use the suggested plans or methods to implement lessons included in teacher's guide. & 3.92 & 0.829 & 14 & High \\
\hline 8 & I apply active learning strategy while teaching the textbook. & 4.50 & 0.730 & 3 & Very high \\
\hline 9 & I use problem-solving method in teaching. & 4.36 & 0.740 & 9 & Very high \\
\hline 10 & I use cooperative learning as one of the important teaching strategies & 4.45 & 0.910 & 5 & Very high \\
\hline 11 & I explain to students how to implement projects in some lessons. & 3.95 & 0.944 & 12 & High \\
\hline 12 & I use survey-based teaching. & 3.87 & 0.932 & 15 & High \\
\hline 13 & I work on enhancing concepts within students. & 4.55 & 0.716 & 2 & Very high \\
\hline 14 & I recommend students to make various leaflets for varied activities. & 3.93 & 1.006 & 13 & High \\
\hline \multicolumn{2}{|c|}{ Average mean score } & 4.29 & 0.466 & & Very high \\
\hline
\end{tabular}

Table 11. Mean scores and standard deviations of participants' responses to items of professional development resources

\begin{tabular}{|c|c|c|c|c|c|}
\hline N. & Professional development resources & M. & SD & Rank & Availability degree \\
\hline 16 & I attend orientation meetings of development projects. & 4.28 & 0.854 & 9 & Very high \\
\hline 17 & I attend seminars related to learning and teaching mathematics. & 4.40 & 0.711 & 4 & Very high \\
\hline 18 & I attend and participate in workshops about mathematics education. & 4.37 & 0.743 & 7 & Very high \\
\hline 19 & I attend and participate in workshops related to educational fields. & 4.29 & 0.723 & 8 & Very high \\
\hline 20 & I attend and participate in workshops related to technical fields. & 4.17 & 0.830 & 12 & High \\
\hline 21 & $\begin{array}{l}\text { I attend conferences, seminars or lectures in new technical programs that are useful for } \\
\text { teaching and learning mathematics. }\end{array}$ & 4.25 & 0.724 & 10 & Very high \\
\hline 22 & I attend training programs related to certain specialization subject in mathematics. & 4.54 & 0.653 & 1 & Very high \\
\hline 23 & I attend training programs related to assessment of student learning. & 4.41 & 0.687 & 3 & Very high \\
\hline 24 & I contact professionals to benefit from mathematics professors at universities. & 4.03 & 0.982 & 14 & High \\
\hline 25 & I benefit from colleagues in specialty area inside and outside school. & 4.48 & 0.693 & 2 & Very high \\
\hline 26 & I continue studying the scientific fields in teaching and learning mathematics. & 4.23 & 0.817 & 11 & Very high \\
\hline 27 & I participate in useful electronic forums related to specialization. & 4.03 & 0.873 & 15 & High \\
\hline 28 & I benefit from competent supervisors. & 4.40 & 0.723 & 5 & Very high \\
\hline 30 & I benefit from programs conducted by some specialized companies in education. & 4.14 & 0.804 & 13 & High \\
\hline \multicolumn{2}{|c|}{ Average mean score } & 4.29 & 0.516 & & Very high \\
\hline
\end{tabular}

Results in Table 11 prove that resources of professional development were available to a very high degree $(\mathrm{M}=4.29)$. Mean scores in this dimension ranged between high $(M=4.03)$ and very high $(M=4.54)$. Teachers' provision with opportunities to attend orientation meetings and seminars related to learning and teaching mathematics specific for development projects; participation in teaching mathematics workshops and technological fields; attending conferences, seminars and lectures about new technology in teaching mathematics were the most important factors in this dimension. Attending training specific to mathematics teaching and assessment; contacting mathematics specialists inside and outside universities; taking part in useful electronic forums; and benefitting from programs provided by some specialized companies were also very helpful to raise participants' perceptions about the resources of professional development.

However, existence of professional development obstacles was believed to be of a moderate degree $(M=3.22)$. Mean scores of participants' responses to items included in this dimension extended from moderate $(M=2.70)$ to high $(M=4.03)$ indicating that all these obstacles really hinder their jobs as teachers. Most of participants believed that their frequent business inside school does not allow me to attend professional development activities $(\mathrm{M}=4.03)$; the weak financial incentives to participate hinders participation in professional development activities $M=4.03$ ); professional development activities conflict with my daily school schedule $(\mathrm{M}=3.90)$; and the implementation of professional development activities requires time outside formal work $(\mathrm{M}=3.80)$ were the most serious obstacles. Participants' viewpoint that the routine, unattractive and boring activities, the weak content and the weak level of program presenters besides the choice of programs' content without consulting the teachers views represent another set of obstacles ahead of professional development programs. The lowest and only weak mean score $(M=2.16)$ was to indicate participants' opinion regarding the fact that attending professional development activities is not helpful. These difficulties can be because development programs are not useful for teachers and normally delivered by the central authority and presented by supervisors without teachers' effective participation. Therefore, it can be strongly claimed that these results corroborate the findings of a set of studies like, for instance $[18,19,20,21,22]$. 
Table 12. Mean scores and standard deviations of participants' responses to items of professional development obstacles

\begin{tabular}{|c|c|c|c|c|c|}
\hline N. & Professional development obstacles & M. & SD & Rank & $\begin{array}{c}\text { Availability } \\
\text { degree }\end{array}$ \\
\hline 31 & Professional development activities conflict with my daily school schedule. & 3.90 & 1.116 & 3 & High \\
\hline 32 & Implementation of professional development activities requires time outside formal work. & 3.80 & 1.110 & 4 & High \\
\hline 33 & My frequent business does not allow me to attend professional development activities. & 4.03 & 1.008 & 1 & High \\
\hline 34 & My academic qualification through my previous education is sufficient. & 2.72 & 1.239 & 13 & Moderate \\
\hline 35 & Attending professional development activities is not helpful for me. & 2.16 & 1.159 & 15 & weak \\
\hline 36 & Professional development activities are routine, boring and unattractive. & 2.70 & 1.311 & 14 & Moderate \\
\hline 37 & There is weakness in the scientific content of the professional development activities. & 2.92 & 1.278 & 11 & Moderate \\
\hline 38 & Providers of professional development activities are of weak levels. & 2.90 & 1.180 & 12 & Moderate \\
\hline 39 & $\begin{array}{l}\text { Professional development activities are determined and chosen without the teacher's knowledge or } \\
\text { involvement. }\end{array}$ & 3.30 & 1.242 & 6 & Moderate \\
\hline 40 & The high financial costs hinder participation in professional development activities. & 2.95 & 1.276 & 10 & Moderate \\
\hline 41 & My frequent connections with colleagues hinder participation in professional development activities. & 3.09 & 1.081 & 8 & Moderate \\
\hline 42 & My frequent family links hinders participation in professional development activities. & 3.54 & 1.237 & 5 & High \\
\hline 43 & The weak financial incentives to participate hinder participation in professional development activities. & 4.03 & 1.100 & 2 & Moderate \\
\hline 44 & School leaders do not encourage me to attend and participate in professional development activities. & 3.01 & 1.436 & 9 & Moderate \\
\hline \multirow[t]{2}{*}{45} & Places for implementing professional development activities are inappropriate. & 3.28 & 1.218 & 7 & Moderate \\
\hline & Average mean score & 3.22 & 0.659 & & Moderate \\
\hline
\end{tabular}

Table 13. Results of $T$. test of participants' responses in accordance with gender

\begin{tabular}{|c|c|c|c|c|c|c|c|}
\hline Dimension & Gender & $\mathbf{N}$. & M. & SD & T value & $P$ value & $\begin{array}{c}\text { Significance } \\
\text { Yes/ No }\end{array}$ \\
\hline \multirow{2}{*}{ Teaching practices } & Male & 42 & 4.16 & 0.516 & \multirow{2}{*}{2.402} & \multirow{2}{*}{0.018} & \multirow{2}{*}{ Yes } \\
\hline & Female & 73 & 4.37 & 0.420 & & & \\
\hline \multirow{2}{*}{ Recourses of professional development } & Male & 42 & 4.17 & 0.501 & \multirow{2}{*}{1.944} & \multirow{2}{*}{0.045} & \multirow{2}{*}{ Yes } \\
\hline & Female & 73 & 4.36 & 0.515 & & & \\
\hline Obstacles of professional development & Male & 42 & 3.07 & 0.648 & 1.921 & 0.037 & Yes \\
\hline \multirow{2}{*}{$\begin{array}{l}\text { Opportunities and challenges of } \\
\text { professional development }\end{array}$} & Male & 42 & 3.17 & 0.596 & \multirow{2}{*}{1.851} & \multirow{2}{*}{0.067} & \multirow{2}{*}{ No } \\
\hline & Female & 73 & 3.41 & 0.712 & & & \\
\hline \multirow{2}{*}{ The whole questionnaire } & Male & 42 & 3.64 & 0.399 & \multirow{2}{*}{3.269} & \multirow{2}{*}{0.001} & \multirow{2}{*}{ Yes } \\
\hline & Female & 73 & 3.86 & 0.357 & & & \\
\hline
\end{tabular}

\subsection{Results Related to the Second Question}

To answer the second question, "Are there any significant differences between participants' responses to the effectiveness of the professional development programs of mathematics teachers due to gender?" T. test was used. Results are presented in Table 13.

Results in Table 13 reveal significant differences in participants' responses in the first dimension in favor of female teachers. A possible explanation for this result is the numerous loads teachers have. The competition between female teachers to attend professional development workshops is normally higher than the competition between male teachers and so they gain better professional development through discussion, observation, experimentation and training and consequently they acquire new skills and attitudes better than male teachers. Another interpretation lies in the fact that professional development for female teachers means a group of correlated aspects like self- cognitive development, professional development inside classrooms' environments besides the interactive, cooperative and social work with others. That is, working with learning groups whether inside or outside school allows the transfer of knowledge and successful experience between female peers better than between male ones. Moreover, female teachers' ability to plan well for students' learning outcomes and for bigger aims not for indetail information; design suitable teaching activities; utilize strategies responsive to students' needs and facilitate effective learning for students and engage them in problem solving seems better than the ability of their male colleagues. In addition, female teachers are more successful than males in promoting students critical and creative thinking, utilizing varies methods for motivating students, managing effectively classroom time and learning material, being capable of self-assessment, students' assessment and feedback provision [24,25,26,32].

\subsection{Results Related to the Third Question}

To answer the third question, "Are there any significant differences between participants' responses to the effectiveness of the professional development programs of mathematics teachers due to the teaching stage?" ANOVA for participants' responses was used. Results are shown in Table 14.

Results in Table 14 indicate apparent differences between participants' responses. To understand the significance of these differences, Scheffe test was used. Results are presented in Table 15. 
Table 14. ANOVA for participants' responses programs regarding the teaching stage

\begin{tabular}{|c|c|c|c|c|c|c|c|}
\hline Dimension & Source of variance & $\begin{array}{l}\text { Sum of } \\
\text { squares }\end{array}$ & DF & $\begin{array}{l}\text { Mean of } \\
\text { Squares }\end{array}$ & F value & $P$ value & $\begin{array}{c}\text { Significance Yes/ } \\
\text { No }\end{array}$ \\
\hline \multirow{3}{*}{ Teaching practices } & Between groups & 0.091 & 2 & 0.046 & \multirow{3}{*}{0.207} & \multirow{3}{*}{0.014} & \multirow{3}{*}{ Yes } \\
\hline & Within groups & 24.693 & 112 & \multirow{2}{*}{0.220} & & & \\
\hline & Total & 24.784 & 114 & & & & \\
\hline \multirow{3}{*}{$\begin{array}{l}\text { Resources of professional } \\
\text { development }\end{array}$} & Between groups & 0.684 & 2 & 0.342 & \multirow{3}{*}{1.290} & \multirow{3}{*}{0.279} & \multirow{3}{*}{ No } \\
\hline & Within groups & 29.705 & 112 & \multirow{2}{*}{0.265} & & & \\
\hline & Total & 30.389 & 114 & & & & \\
\hline \multirow{3}{*}{$\begin{array}{l}\text { Obstacles of professional } \\
\text { development }\end{array}$} & Between groups & 2.785 & 2 & 1.392 & \multirow{3}{*}{3.339} & \multirow{3}{*}{0.039} & \multirow{3}{*}{ Yes } \\
\hline & Within groups & 46.706 & 112 & \multirow{2}{*}{0.417} & & & \\
\hline & Total & 49.491 & 114 & & & & \\
\hline \multirow{3}{*}{ Opportunities and chances } & Between groups & 0.314 & 2 & 0.157 & \multirow{3}{*}{0.336} & \multirow{3}{*}{0.715} & \multirow{3}{*}{ No } \\
\hline & Within groups & 52.240 & 112 & \multirow{2}{*}{0.446} & & & \\
\hline & Total & 52.554 & 114 & & & & \\
\hline \multirow{3}{*}{ The whole questionnaire } & Between groups & 0.694 & 2 & 0.347 & \multirow{3}{*}{2.678} & \multirow{3}{*}{0.037} & \multirow{3}{*}{ Yes } \\
\hline & Within groups & 14.506 & 112 & \multirow{2}{*}{0.130} & & & \\
\hline & Total & 15.199 & 114 & & & & \\
\hline
\end{tabular}

Table 15. Scheffe test for the significance of differences regarding the teaching stage

\begin{tabular}{cccccc}
\hline \multirow{2}{*}{ Dimension } & Teaching stage & Mean score & Elementary & Intermediate & Secondary \\
\cline { 4 - 6 } & & & $\mathbf{4 . 4 2}$ & $\mathbf{3 . 1 0}$ & $\mathbf{3 . 0 9 8}$ \\
\hline \multirow{2}{*}{$\begin{array}{c}\text { Obstacles of professional } \\
\text { development }\end{array}$} & Elementary & 3.42 & - & $*$ & $*$ \\
& Intermediate & 3.10 & - & - & $*$ \\
\hline
\end{tabular}

Statistics in Table 15 reveal that there are significant differences between the responses of participants due to the teaching stage in favor of teachers in intermediate and secondary stages. Shortage of experience among mathematics teachers in the elementary stage in comparison with the experience of peers in the intermediate and secondary stages might be the main source of this variation. Therefore, teachers of elementary stage should be enrolled in programs supervised by specialist educators who can develop them professionally in accordance with new technological trends in teaching. They also have to understand multiplicity in their roles and responsibilities because an elementary mathematics teacher should have mathematical ability, experience in the curriculum outcomes, classroom environment and students' needs. They, moreover, should be capable of planning and implementing skills via the available appropriate opportunities for his students' effective learning and assessment skills to assess their learners successfully. All of these results corroborate the findings of $[16,27,28,29,30]$.

\subsection{Results Related to the Fourth Question}

To answer the fourth question, "Are there any significant differences between participants' responses to the effectiveness of the professional development programs of mathematics teachers due to the teaching experience?" ANOVA was used to identify the differences between participants' responses. Results are presented in Table 16.

Table 16. ANOVA for participants' responses regarding the teaching experience

\begin{tabular}{|c|c|c|c|c|c|c|c|}
\hline Dimension & $\begin{array}{c}\text { Source of } \\
\text { variance }\end{array}$ & $\begin{array}{l}\text { Sum of } \\
\text { squares }\end{array}$ & DF & $\begin{array}{l}\text { Mean of } \\
\text { Squares }\end{array}$ & F value & P value & $\begin{array}{c}\text { Significance Yes/ } \\
\text { No }\end{array}$ \\
\hline \multirow{3}{*}{ Teaching practices } & Between groups & 0.426 & 2 & 0.213 & \multirow{3}{*}{0.979} & \multirow{3}{*}{0.039} & \multirow{3}{*}{ Yes } \\
\hline & Within groups & 24.358 & 112 & \multirow{2}{*}{0.217} & & & \\
\hline & Total & 24.784 & 114 & & & & \\
\hline \multirow{3}{*}{$\begin{array}{l}\text { Recourses of professional } \\
\text { development }\end{array}$} & Between groups & 1.398 & 2 & 0.699 & \multirow{3}{*}{2.701} & \multirow{3}{*}{0.027} & \multirow{3}{*}{ Yes } \\
\hline & Within groups & 28.991 & 112 & \multirow{2}{*}{0.259} & & & \\
\hline & Total & 30.389 & 114 & & & & \\
\hline \multirow{3}{*}{$\begin{array}{l}\text { Obstacles of professional } \\
\text { development }\end{array}$} & Between groups & 1.430 & 2 & 0.715 & \multirow{3}{*}{1.666} & \multirow{3}{*}{0.194} & \multirow{3}{*}{ No } \\
\hline & Within groups & 48.061 & 112 & \multirow{2}{*}{0.429} & & & \\
\hline & Total & 49.491 & 114 & & & & \\
\hline \multirow{3}{*}{$\begin{array}{l}\text { Opportunities and } \\
\text { challenges of professional } \\
\text { development }\end{array}$} & Between groups & 0.428 & 2 & 0.465 & \multirow{3}{*}{0.460} & \multirow{3}{*}{0.633} & \multirow{3}{*}{ No } \\
\hline & Within groups & 52.126 & 112 & \multirow{2}{*}{0.214} & & & \\
\hline & Total & 52.554 & 114 & & & & \\
\hline \multirow{3}{*}{ The whole questionnaire } & Between groups & 0.647 & 2 & 0.323 & \multirow{3}{*}{2.489} & \multirow{3}{*}{0.048} & \multirow{3}{*}{ Yes } \\
\hline & Within groups & 14.553 & 112 & \multirow{2}{*}{0.130} & & & \\
\hline & Total & 15.199 & 114 & & & & \\
\hline
\end{tabular}


Findings, in Table 16, reveal significant differences between participants' responses to items in the first dimension (teaching practices) and second one (resources of professional development). But, there were no significant differences in their responses to the third dimension (obstacles of professional development) and the fourth one Opportunities and challenges of professional development of professional development. These results can be due to the development of the teacher's sense of direct responsibility to develop himself professionally, define an overall vision to interact with activities of professional development, and allow full-time spaces to practice activities that develop his/her professional and educational skills. Teachers can develop their professional skills through training programs, visits exchange, technical guidance, mentoring, qualification, and providing educational counseling to solve problems. Promoting the teacher's professional level can be through relevant training centers, which are based on disseminating successful experiences of teachers, solving problems facing them, and enrolling them in pre-service training courses. The existence of significant differences in participants' responses to the third and fourth dimensions may be referred to the lack of sufficient tools to evaluate professional development programs, and the weak relationship between professional development programs on, one hand and classroom practices and student achievement on the other hand. Therefore, teachers who teach the same level should be trained together and separated from teachers of intermediate and secondary stages. There should also be annual follow-up programs that are financially rewarded as incentives. All these results are in congruence with the findings of [19,20,21,22,31,34,35].

\subsection{Results Related to the Fifth Question}

To answer the fifth question "Are there any significant differences between participants' responses to the effectiveness of the professional development programs of mathematics teachers due to the number of professional development programs?" ANOVA was used to identify the differences between participants' responses. Results are presented in Table 17.

Table 17 indicates significant differences between participants' responses to the first and fourth dimensions.
Nevertheless, there were no significant differences between their responses to the second and third dimensions. To understand in favor of which dimension these differences were, Scheffe test was carried out. Results are in Table 18.

Results in Table 18 show that there are significant differences in favor of more than five development programs whether at the level of Opportunities and challenges of professional development, or at the level of the questionnaire as a whole.This can be due to the fact that professional development programs locally and nationally affect policies and practices that have impact on their work through clear measurable standards at the individual and institutional level, on one hand and o cooperation between specialties based on based on the interdisciplinary partnership philosophy to meet at a common point that is beneficial in the development of the educational system outcomes in schools, the teachers, and other stakeholders involved in the educational process, diversity and fairness in practices. Professional development programs should provide equitable opportunities for learning and evaluation of educational policies and practices to support learning outcomes, diversity of participants, and use of necessary authorities and resources to clarify the mission of these programs. They should also establish organizational structures that support the development of different learning stages of education, teachers and other stakeholders. Programs and activities of professional development should be prepared according to teachers' needs, and in light of his professional experience level and personality characteristics to support his pre-service preparation. That is, professional development has to be a critical factor in all educational reform and improvement programs. Therefore, professional development programs should be an integral part of this improvement plan, consistency of objectives and content with the academic learning basic requirements and grade level. The existence of clear and aimful philosophy and objectives upon which these programs are built, in accordance with teachers' training needs to ensure their effective participation and nominal attendance elimination without any benefit from these programs. In short, these results can be considered in agreement with the findings of a set of studies in this area like for example, [22,28,29,35].

Table 17. ANOVA for participants' responses regarding the number of professional programs they received

\begin{tabular}{|c|c|c|c|c|c|c|c|}
\hline Dimension & Source of variance & Sum of squares & DF & Mean of squares & F value & $P$ value & Significance Yes/ No \\
\hline \multirow{3}{*}{ Teaching practices } & Between groups & 0.376 & 2 & 0.188 & \multirow{3}{*}{0.863} & \multirow{3}{*}{0.025} & \multirow{3}{*}{ Yes } \\
\hline & Within groups & 24.408 & 112 & \multirow{2}{*}{0.218} & & & \\
\hline & Total & 24.784 & 114 & & & & \\
\hline \multirow{3}{*}{$\begin{array}{l}\text { Resources of professional } \\
\text { development }\end{array}$} & Between groups & 0.142 & 2 & 0.071 & \multirow[t]{3}{*}{0.262} & \multirow[t]{3}{*}{0.770} & \multirow[t]{3}{*}{ No } \\
\hline & Within groups & 30.248 & 112 & 0.270 & & & \\
\hline & Total & 30.389 & 114 & & & & \\
\hline \multirow{3}{*}{$\begin{array}{l}\text { Obstacles of professional } \\
\text { development }\end{array}$} & Between groups & 1.330 & 2 & 0.665 & \multirow{3}{*}{1.547} & \multirow{3}{*}{0.017} & \multirow{3}{*}{ No } \\
\hline & Within groups & 48.161 & 112 & 0.430 & & & \\
\hline & Total & 49.491 & 114 & & & & \\
\hline \multirow{3}{*}{$\begin{array}{l}\text { Opportunities and } \\
\text { challenges of professional } \\
\text { development }\end{array}$} & Between groups & 3.027 & 2 & 1.514 & \multirow{3}{*}{3.423} & \multirow{3}{*}{0.036} & \multirow{3}{*}{ Yes } \\
\hline & Within groups & 49.526 & 112 & 0.442 & & & \\
\hline & Total & 52.554 & 114 & & & & \\
\hline \multirow{3}{*}{ The whole questionnaire } & Between groups & 0.828 & 2 & 0.414 & \multirow{3}{*}{3.228} & \multirow{3}{*}{0.043} & \multirow{3}{*}{ Yes } \\
\hline & Within groups & 14.371 & 112 & 0.128 & & & \\
\hline & Total & 15.199 & 114 & & & & \\
\hline
\end{tabular}


Table 18. Scheffe test for the significance of differences regarding the number of development programs they received

\begin{tabular}{|c|c|c|c|c|c|}
\hline \multirow{2}{*}{ Dimension } & \multirow{2}{*}{ Number of development programs } & \multirow{2}{*}{$\mathbf{M}$} & None & 1-5 & More than 5 \\
\hline & & & 3.12 & 3.42 & 3.53 \\
\hline \multirow{3}{*}{ Opportunities and challenges of professional development } & None & 3.12 & - & - & - \\
\hline & $1-5$ & 3.42 & $*$ & - & - \\
\hline & More than 5 & 3.52 & $*$ & $*$ & - \\
\hline \multirow{4}{*}{ The whole questionnaire } & & & 3.68 & 3.84 & 3.85 \\
\hline & None & 3.68 & & & \\
\hline & $1-5$ & 3.84 & & & \\
\hline & More than 5 & 3.85 & & & \\
\hline
\end{tabular}

Table 19. Means and standard deviations for participants' responses regarding Opportunities and challenges of professional development

\begin{tabular}{|c|c|c|c|c|c|}
\hline $\mathbf{N}$ & Obstacles & $\mathbf{M}$ & SD & Rank & $\begin{array}{c}\text { Degree of } \\
\text { availability }\end{array}$ \\
\hline 46 & Mathematics teacher has no time to carry out extra activities. & 4.15 & 1.118 & 4 & High \\
\hline 47 & Mathematics teacher has difficulty in following the latest related to his specialty. & 3.60 & 1.107 & 5 & High \\
\hline 48 & Mathematics teacher cannot carry out treatment plans to help low achievement students. & 3.10 & 1.318 & 11 & Moderate \\
\hline 49 & Mathematics teacher is unable to implement enrichment plans for high achievement students. & 3.08 & 1.285 & 12 & Moderate \\
\hline 50 & Mathematics teacher has a challenge in discovering the talented inside the classroom. & 3.54 & 1.293 & 7 & High \\
\hline 51 & The large number of students in classroom is a serious problem for the teacher. & 4.44 & 0.929 & 1 & Very high \\
\hline 52 & Course length is one of the biggest challenges for mathematics teacher. & 4.22 & 0.989 & 2 & Very high \\
\hline 53 & The frequent absence of students hinders implementation of the teachers' teaching plans. & 4.22 & 1.007 & 3 & Very high \\
\hline 54 & Changeable weather conditions hinder implementation of the teacher's on time plans. & 3.55 & 1.118 & 6 & High \\
\hline 55 & The technical tools that are easy for students to use make them not interested in the lesson. & 3.51 & 1.293 & 8 & High \\
\hline 56 & $\begin{array}{l}\text { Mathematics teacher has great opportunities to attend various professional development } \\
\text { programs. }\end{array}$ & 3.05 & 1.248 & 13 & Moderate \\
\hline 57 & Mathematics teacher has opportunities to easily study in his / her field of specialization. & 3.04 & 1.273 & 14 & Moderate \\
\hline 58 & Mathematics teacher can obtain a higher degree when he likes. & 3.20 & 1.306 & 10 & Moderate \\
\hline 59 & Mathematics teacher is provided with special services and facilities while traveling. & 2.78 & 1.626 & 15 & Moderate \\
\hline 60 & Mathematics teacher feels valued and respected by the community. & 3.37 & 1.239 & 9 & Moderate \\
\hline 61 & Mathematics teacher gets valuable prizes for his efforts. & 2.59 & 1.432 & 16 & Weak \\
\hline 62 & Mathematics teacher enjoys all various services in health clubs. & 2.55 & 1.488 & 18 & Weak \\
\hline 63 & Mathematics teacher has the priority when going to any institution in recognition of his efforts. & 2.54 & 1.546 & 19 & Weak \\
\hline 64 & Mathematics teacher is granted financial rewards for his outstanding efforts. & 2.57 & 1.623 & 17 & Weak \\
\hline \multicolumn{2}{|c|}{ Average mean score } & 3.32 & 0.679 & \multicolumn{2}{|c|}{ Moderate } \\
\hline
\end{tabular}

\subsection{Results Related to the Sixth Question}

To answer the sixth question, "What are the main opportunities and challenges of professional development programs of mathematics teachers in Najran?" Mean scores and standard deviations of participants' responses were extracted. Results are shown in Table 19.

Results in Table 19 indicate that there are some opportunities and challenges facing mathematics teachers' professional development programs ranging from very high $(M=4.44)$ and moderate $(M=2.54$. however, items number $61,62,63$, and 64 whose mean scores were $(2.59$, $2.55,2.54$, and 2.57) respectively were believed to be weak opportunities and challenges. This result can be due to rapid developments in scientific and media aspects accompanied by rapid change in social and educational aspects. A teacher is, therefore, has to interact with these developments in a way that serves his role in light of new educational theories. He has to achieve a qualitative change in teaching and learning that looks at the learner as the center of the educational process. Therefore, he has to move from lecturing into a facilitator who helps students to discover new knowledge using various current teaching methods. He has to distinguish and identify the educational problems in the field while implementing new curricula. He also has to deepen communication with colleagues and play a significant role in developing the educational process. In addition, mathematics teacher in Saudi Arabia has to keep up with the latest in education and apply it in accordance with the international standards, particularly after the adoption of using McGraw hill series to develop mathematics and science curricula. Thus, it is very important to reconsider developing professionally mathematics teachers through programs that fulfill these new needs in light of such developed curriculum. Therefore, these results can be seen in agreement with the results of $[8,18,22,31,32,33,34]$.

\section{Recommendations}

\subsection{Recommendations for Educational Stakeholders}

Stakeholders of developing mathematics teachers professionally are recommended to:

1. Pay attention to mathematics teachers' professional development programs in Saudi Arabia that fulfill their needs in light of the professional acceleration of teachers of mathematics at a global level.

2. Develop the professional skills of mathematics teachers through training programs, visit exchange and educational supervision. 
3. Develop programs of college of education programs that can contribute to organizing training programs, supervision, qualification and providing educational consultations to solve problems.

4. Be concerned to achieve quality in education, form positive trends towards this profession, enable teachers to face varied educational changes and reforms, through showing them the problems of the educational system, and educating them about their role in solving them on one hand, and improve the learning process by improving their theoretical and practical skills.

5. Enable mathematics teachers to walk along with and apply developments in the field of teaching and learning theories that achieve efficacy in teaching.

6. Enable mathematics teachers to walk along with the latest in the curricula content.

7. Enable mathematics teachers to acquire the skills of educational technology utilization in teaching mathematics.

8. Develop the creative aspects of teachers, encourage them to be innovative at work, and cooperate with colleagues.

9. Adopt programs that are based on the activation of the learners' role.

10. Consider the professional development of mathematics teachers as a critical factor in all educational reforms and improvement programs.

\subsection{Recommendations for Further Research}

Researchers are recommended to conduct studies that aim to

1. Survey the viewpoints of educational supervisors to identify the training needs of mathematics teachers in the intermediate stage in light of the requirements of contemporary professional standards achievement.

2. Evaluate professional development programs for mathematics teachers at different levels.

\section{References}

[1] Al Momani, K. (2007). Planning for Teachers Professional Growth, Journal of Teacher. Retrieved on 8/7/2019, www.Almualem.net.

[2] Abdul Hamid, R. (2017). Effectiveness of a Proposed Training Program Using Educational Tools of Web 2.0 for the Professional Development of Intermediate School Mathematics Teachers in Light of their Training Needs for Teaching Developed Curricula in Saudi Arabia. Journal of Arab Studies in Education and Psychology (84), 63-109.

[3] Harris, A. \& Muijs, D. (2007). Teacher Leadership in Action: Three Case Studies of Contrasting Schools, Education Management and Administration, 35, I1, 95.

[4] Shalash, B. \& Harzallah, H. (2017). Educational Supervision and its Relationship With professional Development of Mathematics Teachers in Upper Basic Stage in Palestine, Journal of Al-Quds Open University for Educational and Psychological Research and Studies, (17), 293-311.

[5] Al Elayyan, F. (2010). A proposal for Self-Professional Development of Mathematics Teachers in Intermediate Stage from the Viewpoint of specialists and practitioners. Unpublished MA. Thesis, Faculty of Education, Umm Al-Qura University.

[6] Awaji, B. (2014). Availability of Professional Competencies Required by Mathematics Teachers to Teach Mathematics Courses in the Intermediate Stage, Journal of Educational Mathematics 17 (7), 61-94.

[7] Anthony, G. \& Walshaw, M. (2009).Characteristics of Effective Teaching of Mathematics: A View from the West, Journal of mathematics Education, 2 ( I2), 147-164.

[8] Al Khatib, M. (2012). A Proposal for Contemporary Professional Standards for Mathematics Teachers and their Availability among a Group of Mathematics Teachers in Saudi Arabia, Journal of Al Najah University for Research, Humanities, 26 (2), 257-298.

[9] Simon, S. \& Campbell, S. (2012). Teacher Learning and Professional Development in Science Education. In Fraser, Barry J. Tobin, Kenneth G. \& McRobbie, Campbell J. (Eds). Second International Handbooks of Education. (24), 295-306), London New York: Springer.

[10] Lee, H. (2005). Developing a Professional Development Program Model Based on Teachers Need. Professional Educator, 27, I1-2, 39-49.

[11] Ruwaily, S. (2010). Tasks of Educational Supervisor in Developing Professional Growth of Mathematics Teachers in the Intermediate Stage, Journal of Education World, Egypt, 10 (30), 334-396.

[12] Postholm, M. B. (2012). Teacher Professional Development: A Theoretical Review, Journal of Educational Research, 54(4), 405-429.

[13] Al Oafi, M. (2014). Professional Development of Arab Teacher in Light of Globalization Challenges Monitoring Reality and Looking Ahead, Jerash Journal for Research and Studies, Jerash University, 15 (2), 240-261.

[14] Al Tayyar, A. A. O. (2018). A Proposal for the Role of Supervisor Teacher in the Professional Development of Mathematics Teacher in light of McGraw Hill Series, Unpublished MA. Thesis, College of Education, Qassim University.

[15] Sabri, R. (2018). Effectiveness of a Proposed Training Program for Designing Teaching Attitudes Using McCarthy Model to Develop Some Requirements of Professional Competency among Mathematics Teachers and Developing Mathematical Confidence among Elementary School Students, Journal of Mathematics Education, 21 (1), 25-80.

[16] Alqahtani, G.(2018). Professional Development of Mathematics Teachers in Integrating Digital Technology: Comparative Study. International Journal of Educational Psychological Studies, 3 (I2) 552-583.

[17] Kearny, M. \& Maher, D. (2013). Mobile Learning in Maths Teacher Education: Using Ipad to Support Pre-Service Teacher Professional Development, Australian Educational Computing Journal, 27(I1).

[18] Al Balawi, A. \& Ghaleb, R. (2012). Professional Development Needs of Public Education Mathematics Teachers in Saudi Arabia, Journal of Educational and Psychological Studies, Sultan Qaboos University, 6 (1), 114-132.

[19] Al Astal, I. (2015). The needs of Professional Development of Mathematics Teachers at the Upper Basic Stage in Gaza Schools in Light of School mathematics Standards, Journal of Education College in Banha, 26, (101), 3-

[20] Abu Al-Hasan, T. (2016). Needs of Professional Development Needs of Mathematics Teachers in Public Elementary Schools of Languages, Journal of Mathematics Education, 19(4), 62-129.

[21] Abu Shawish, F. (2016). Obstacles of School-Based Teacher Professional Development Program (SBTD) in UNRWA Schools in Gaza Districts and How to Overcome them, Unpublished MA Thesis, Faculty of Education, Islamic University, Gaza.

[22] Joadeh, S. (2019). Professional Development of Mathematics Teachers in Tabuk in Light of 2030 Vision and its Relationship with Reflective Practices and Self-Effectiveness Teaching, Journal of Educational Mathematics, 22 (1), 181-231.

[23] Shaye, P. (2015). Professional Development for Early Childhood Educators: Efforts to Improve Math and Science Learning Opportunities in Early Childhood Classrooms, Journal of Educational Psychology, 107 (I2), 407-422.

[24] Al Ghamdi, M. (2018). Self-Assessment of Math Teachers in Saudi Arabia in Light of NCTM Standards for Professional Development, Al Fat'h Journal, (75), 97-138.

[25] Ennab, R. \& Al Shonnaq, M. (2019). Training Needs of Mathematics Teachers at the Upper Basic Stage According to their Future Roles in Knowledge Economy. Journal of Educational Sciences, 46 (1), 439-458. 
[26] Al Enezi, Z. (2019). Training Needs of Elementary School Mathematics Teachers in Tabuk in light of the Requirements of Achieving Contemporary Professional Standards from their and their Educational Supervisors Viewpoint, Journal of College of Education, Assiut University, 35 (3), 57-73.

[27] Mohammed, A. (2015). A Proposed Program in professional development of Mathematics Teachers at School of Excellence for Science and Technology in Light of Quality Standards, Ain Shams University, Adult Education Center, (18), 193-224.

[28] Al Fajam, H., Al Mansouri, M. \& Al Dowailah, A. (2017). Reality of Professional Growth of Science and Mathematics Teachers in Elementary Schools in Kuwait, Journal of the College of Education, Al-Azhar University, 1 (176), 582-614.

[29] Al Yahya, I. A. M. (2017). Reality of Professional Development of Secondary School Teachers from the Perspective of Teachers and Supervisors in Dawadmi, Journal of the College of Education, Assiut University, 33 (1), 56-101.

[30] Al Maleki, A. (2018). The Extent to which Mathematics Teachers at Intermediate Stage Own some of the Skills of Teaching Developed Mathematics in Jeddah. International Interdisciplinary Journal of Educational, 7 (3), 89-100.
[31] Al Balawi, A., \& Al Rajeh, N. (2012). Reality of Professional Development of Mathematics Teachers in Saudi Arabia, Message of Education and Psychology, Saudi Arabia, (38), 43-78.

[32] Al Shaye'a, F. (2013). Reality of Teacher Professional Development Accompanying Project of Mathematics and Natural Sciences Development in Public Education in Saudi Arabia from the Viewpoint of Program Providers, Message of Education and Psychology, Saudi Arabia (42), 58-92.

[33] Al Rajeh, N. \& Al Zain, H. (2015). Reality of Digital Technologies in Supporting Professional Development of Mathematics Female Teachers, Journal of Arab Studies in Education and Psychology (64), 389-415.

[34] Al Howayhi, M. (2015). A Proposal for Professional Development of Public Education Teacher in Saudi Arabia in Light of Academic Accreditation Standards, Journal of Azhar, College of Education, 3 (166), 274-386.

[35] Hassan, H. \& Khalil, I. (2017). Attitudes of Mathematics and Science Teachers towards Professional Development Programs and their Relationship with Some Variables, Journal of Educational Sciences, 2 (2), 97-122.

(C) The Author(s) 2019. This article is an open access article distributed under the terms and conditions of the Creative Commons Attribution (CC BY) license (http://creativecommons.org/licenses/by/4.0/). 